\title{
On the Charge Partitioning Between $c$ and $z$ Fragments Formed After Electron-Capture Induced Dissociation of Charge-Tagged Lys-Lys and Ala-Lys Dipeptide Dications
}

\author{
Camilla Skinnerup Jensen, Anne I. S. Holm, Henning Zettergren, \\ Jakob B. Overgaard, Preben Hvelplund, and Steen Brøndsted Nielsen \\ Department of Physics and Astronomy, Aarhus University, Aarhus, Denmark
}

\begin{abstract}
Here we report on the charge partition between $c$ and $z$ fragments formed after femtosecond collisional electron-transfer from Cs atoms to charge-tagged peptide dications. Peptides chosen for study were Ala-Lys (AK) and Lys-Lys (KK) where one or both of the lysine $\varepsilon$-amino groups were trimethylated to provide one or two fixed charges. For peptides with only one charge tag, the other charge was obtained by protonation of an amino group. In some experiments the ammonium group was tagged by 18-crown-6-ether (CE). Since recombination energies decrease in the order: $\mathrm{MeNH}_{3}{ }^{+}>\mathrm{NMe}_{4}{ }^{+}>\mathrm{MeNH}_{3}{ }^{+}(\mathrm{CE})>\mathrm{NMe}_{4}{ }^{+}(\mathrm{CE})$, it is possible to change the probability for the transferred electron to end up at either the $\mathrm{N}$-terminal or the $\mathrm{C}$-terminal residue by $\mathrm{CE}$ attachment. We find, however, that the individual recombination energies have little influence on the relative ratio between the yield of $c$ and $z$ ions as long as there are no mobile protons that can be transferred between the two fragments. Our results can be accounted for by the Utah-Washington model where the electron is captured into an amide $\pi^{*}$ orbital that weakens the $\mathrm{N}-\mathrm{C}_{\alpha}$ bond and causes its breakage, followed by proton, electron, or hydrogen transfer between the $c$ and $z$ fragments that stay together as an ion-molecule complex for some time. The data are also in accordance with the notion that an amide group competes with the charged groups for the electron. Electron capture by charged groups results in loss of small neutrals such as hydrogen and ammonia. (J Am Soc Mass Spectrom 2009, 20, 1881-1889) (c) 2009 Published by Elsevier Inc. on behalf of American Society for Mass Spectrometry
\end{abstract}

$\mathrm{M}$ ass spectrometry is used extensively to sequence peptides and proteins (proteomics). Electron capture dissociation (ECD) [1-3] or electron-transfer dissociation (ETD) [4-8], where either free electrons combine with multiply charged cations in the cell of a Fourier Transform Ion Cyclotron Resonance instrument or electron-transfer occurs from anions to cations typically in a linear ion trap, provide sequence coverage that is complementary to those from other excitation methods. Importantly, ECD and ETD also leave posttranslational modifications untouched [1,9]. The dominant fragmentation channels after electron capture are ammonia loss, hydrogen loss, and $\mathrm{N}-\mathrm{C}_{\alpha}$ bond cleavage to give $c$ and $z$ fragments. The latter are used to obtain the amino acid sequence.

The mechanism for the selective cleavage of $\mathrm{N}-\mathrm{C}_{\alpha}$ bonds has been up for much debate. Some of the questions that have been addressed relate to whether the dissociation is statistical or not [1,10-13], where in the peptide the electron is captured [10, 14-18], the

Address reprint requests to Professor S. Brøndsted Nielsen, Department of Physics and Astronomy, Aarhus University, Ny Munkegade, DK-8000 Aarhus C, Denmark. E-mail: sbn@phys.au.dk significance of the recombination energy of the capture site $[12,19-22]$, the delocalization of the electronic state and how it evolves in time [23], the importance of internal ionic hydrogen bonding and conformational heterogeneity $[9,24-30]$, hydrogen atom and proton transfer processes [31-38], the role of partial solvation [39-41], and how the fragmentation is influenced by the introduction of fixed permanent charges (charge tags) or metal cations [42-51]. Most likely, one single mechanism is not sufficient to explain all data published by various groups.

We have concentrated our work on small peptides, mainly dipeptides and tripeptides that can be made as doubly charged ions [30, 38, 39, 41, 52, 53]. Such systems offer several advantages over larger peptides: there are few reaction channels, which renders the peaks in the spectra easy to assign. The small size dictates somewhat unfolded structures to maximize the distance between the two positive charges. The number of important conformers is therefore limited, which is of importance for quantum chemical modeling [23]. In our experiments, we let the ions interact with cesium or sodium atoms in ultrashort collisions (few fs), which implies nearly vertical electron-transfer considering that vibra- 
tional periods are tens or hundreds of fs. This is again beneficial for modeling since the initial structure of the charge-reduced species is known, being the same as that of the parent dication. Fragmentation after electron-transfer is monitored on a microsecond time scale in contrast to ECD and ETD where the time scale is tens of ms. We have named this technique electron capture induced dissociation (ECID). Despite the very large differences between ECID and ECD with respect to energetics and time for the electron-transfer process as well as the sampling time for dissociation, the outcome is surprisingly similar as we have demonstrated for doubly protonated bradykinin and Substance P [53].

In this work, we present ECID results on chargetagged $\mathrm{AK}$ and $\mathrm{KK}$ dipeptides where a permanent charge is at fixed known positions (see Figure 1). Either one or both of the lysine $\varepsilon$-amino groups in the case of KK are trimethylated. The other charge is introduced by protonation of an amino group. The charge tag alters the physics in several ways. (1) Since the charge tag is not engaged in internal ionic hydrogen bonding, the peptide is less folded. For example, in the case of [KK + $2 \mathrm{H}]^{2+}$, Turecek and coworkers [22] calculated that the two $N$-terminal amino groups share a proton and that the C-terminal lysine ammonium group hydrogen bonds to the carboxylic acid group. (2) The recombination energy $(R E)$ of quaternary ammonium is smaller than that of ammonium, and the two sites do therefore not capture the electron with equal probability. (3) The
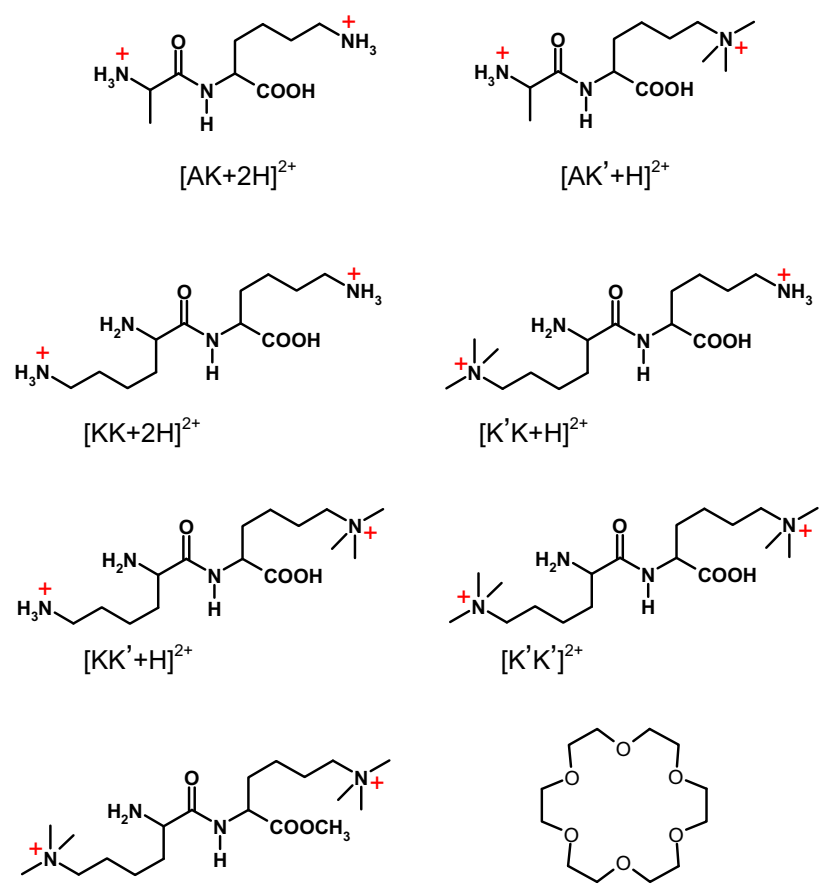

$\left[K^{\prime} K^{\prime \prime}\right]^{2+}$

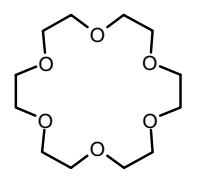

CE

Figure 1. Peptides with permanent charge tags that were subjects for study. In some experiments, the ammonium group was tagged with 18-crown-6-ether (CE). charge tag does not possess mobile protons that can be transferred between the $c$ and $z$ fragments, which may affect the ratio between the yield of $c$ and $z$ ions. Charge-tagging of an ammonium group with 18-crown6-ether (CE) causes similar changes [49], but in this case the $R E$ is lowered even more relative to that of ammonium because of loss of the strong complexation energy upon electron attachment. Vertical REs for singly charged model cations are $4.3 \mathrm{eV}\left(\mathrm{MeNH}_{3}{ }^{+}\right), 3.1 \mathrm{eV}\left(\mathrm{NMe}_{4}{ }^{+}\right), 2.3$ $\mathrm{eV}\left(\mathrm{NMe}_{4}{ }^{+}(\mathrm{CE})\right)$, and $2.1 \mathrm{eV}\left(\mathrm{MeNH}_{3}{ }^{+}(\mathrm{CE})\right)$, calculated at the B3LYP/6-311++G(2d,p) level of theory. These energies are higher for dications by the Coulomb repulsion energy between the two charges. The fact that the $R E$ is lower of an ammonium group tagged with $C E$ than that of a trimethylated ammonium group implies that we can to some extent direct the electron to the end we want. Here we explore the importance of energetics, employing the $\mathrm{AK}$ and $\mathrm{KK}$ dipeptides as model systems.

\section{Experimental}

Synthetic peptides and 18-crown-6-ether were purchased from Sigma-Aldrich (AK, KK, CE) and from CASLO Laboratory ApS (Lyngby, Denmark) (AK', KK', $\mathrm{K}^{\prime} \mathrm{K}, \mathrm{K}^{\prime} \mathrm{K}^{\prime}$, the prime refers to the lysine $\varepsilon$-amino group being trimethylated). Peptides were dissolved in water/methanol (1:1) with acetic acid added (10\% in volume), and $\mathrm{CE}$ was added in different amounts to produce complexes with either one or two CEs attached. The methyl ester of $\mathrm{K}^{\prime} \mathrm{K}^{\prime}$, denoted $\mathrm{K}^{\prime} \mathrm{K}^{\prime \prime}$, was made by the addition of one droplet of concentrated $\mathrm{H}_{2} \mathrm{SO}_{4}$ to the compound dissolved in methanol (1 mL); the solution was kept for a couple of days at roomtemperature before $1 \mathrm{~mL}$ of water was added. Ions were produced by electrospray ionization of the peptide solutions, and the source was on a platform held at a voltage of $50 \mathrm{kV}$. Doubly charged ions were accelerated to $100-\mathrm{keV}$ kinetic energies, and those with the proper mass-to-charge ratio were selected by a bending magnet $[54,55]$. The ions then collided with cesium atoms in a collision cell. The product ions were separated according to kinetic energy per charge by a hemispherical electrostatic analyzer and counted by a channeltron detector.

\section{Theory}

Density functional theory (DFT) calculations were carried out using the Gaussian-03 program [56]. The hybrid B3LYP functional that combines the Becke's three parameter nonlocal hybrid exchange potential [57] with the nonlocal correlation functional of Lee et al. [58] was used. This functional in combination with the $6-31+G(d, p)$ basis set has previously been used by Turecek and coworkers [23] in a detailed exploration of the potential energy surface of $[\mathrm{KK}+2 \mathrm{H}]^{2+}$, which motivates the use of the same level of theory in this work. However, such a rigorous approach is beyond the scope of the present study. Instead, we used the two most stable [KK + 
$2 \mathrm{H}]^{2+}$ structures (denoted $7^{2+}$ and $8^{2+}$ in reference [23]) to build initial guess structures for geometry optimizations of $\left[\mathrm{K}^{\prime} \mathrm{K}+\mathrm{H}\right]^{2+},\left[\mathrm{KK}^{\prime}+\mathrm{H}\right]^{2+},\left[\mathrm{K}^{\prime} \mathrm{K}^{\prime}\right]^{2+},\left[\mathrm{K}^{\prime} \mathrm{K}+\right.$ $\mathrm{H}]^{2+}(\mathrm{CE})$, and $\left[\mathrm{KK}^{\prime}+\mathrm{H}\right]^{2+}(\mathrm{CE})$ at the B3LYP/6-31 + $G(d, p)$ level of theory. It is important to note that we cannot rule out that there may be other isomers present under the experimental conditions, and thus the presented structures may only be regarded as typical structures aimed to aid the interpretation of the experimental results. The two structures are similar and remain rather close in energy $(<0.2 \mathrm{eV})$ for a given charge tag position and type. In the following discussion, we, however, only refer to the most stable structures.

In addition, we extracted the vertical recombination energies from the difference between the dication energies and the energies from single point calculations of the charged reduced species (i.e., in the geometries of the dications). As a complement, we carried out calculations of the (vertical) recombination energies of small singly charged model systems $\left(\mathrm{MeNH}_{3}{ }^{+}, \mathrm{NMe}_{4}{ }^{+}\right.$, $\mathrm{MeNH}_{3}{ }^{+}(\mathrm{CE})$, and $\mathrm{NMe}_{4}{ }^{+}(\mathrm{CE})$ ) at the B3LYP /6$311++G(2 d, p)$ level.

\section{Results and Discussion}

ECID spectra of $[\mathrm{KK}+2 \mathrm{H}]^{2+},\left[\mathrm{K}^{\prime} \mathrm{K}+\mathrm{H}\right]^{2+},\left[\mathrm{KK}^{\prime}+\right.$ $H]^{2+}$, and $\left[K^{\prime} K^{\prime}\right]^{2+}$ are shown in Figure $2 a-d$, and the branching ratios between the different dissociation channels after electron capture are summarized in Table 1. For $\mathrm{KK}$, the dominant channels after electron capture involve the formation of $[c+\mathrm{H}]^{+}$(denoted a $c^{\prime}$ fragment in the literature), loss of hydrogen, and loss of ammonia (Figure 2a) as was earlier reported [38]. Hydrogen loss is more prevalent than ammonia loss. Experiments on $\mathrm{K}^{\prime} \mathrm{K}$ also led to $[c+\mathrm{H}]^{+}$ions and hydrogen loss while the $\mathrm{NH}_{3}$ loss channel is switched off (Figure 2b). From ${ }^{15} \mathrm{~N}$-labeling experiments on KK, it has been shown that ammonia loss occurs exclusively from the $\mathrm{N}$-terminal amino end [38], and we therefore ascribe the absence of ammonia loss from $\left[\mathrm{K}^{\prime} \mathrm{K}+\mathrm{H}\right]^{2+}$ to be due to the ionizing proton residing on the $\mathrm{C}$ terminal lysine amino group in accordance with calculations (Figure 3a). The origin of hydrogen loss is expectedly from the neutralized ammonium group, and this channel has increased in importance compared to KK. There is a tiny peak that corresponds to the ion that has lost a methyl group, which implies that some electron-transfer from Cs occurs to the quaternary ammonium group.

Charge-tagging of the other $\varepsilon$-amino group, $\mathrm{KK}^{\prime}$, resulted in the formation of $z^{+}$ions, and no $[c+\mathrm{H}]^{+}$ ions could with certainty be detected (Figure 2c). It is worth to notice that the probability for $\mathrm{N}-\mathrm{C}_{\alpha}$ cleavage is lower than that for KK and $K^{\prime} K$. Both hydrogen and ammonia loss occurred from $\left[\mathrm{KK}^{\prime}+\mathrm{H}\right]^{+\bullet}$, which indicates that the excess proton is close to the $\mathrm{N}$ terminal amino group. In fact, the proton is shared between the two amino groups (Figure 3b). Interestingly, ammonia loss occurred with similar probability

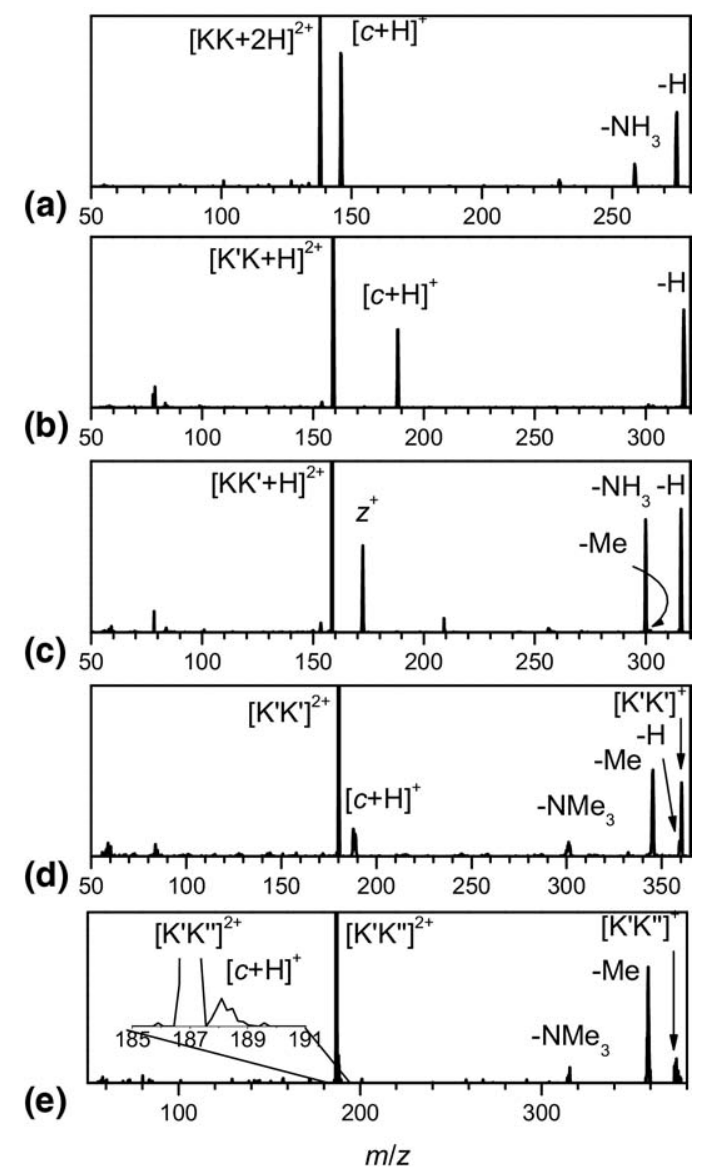

Figure 2. ECID spectra of (a) $[\mathrm{KK}+2 \mathrm{H}]^{2+}\left(\mathrm{m} / z\right.$ 138), (b) $\left[\mathrm{K}^{\prime} \mathrm{K}+\right.$ $\mathrm{H}^{2+}(m / z 159),(\mathbf{c})\left[\mathrm{KK}^{\prime}+\mathrm{H}\right]^{2+}(m / z 159),(\mathbf{d})\left[\mathrm{K}^{\prime} \mathrm{K}^{\prime}\right]^{2+}(m / z 180)$, and $(\mathbf{e})\left[K^{\prime} K^{\prime \prime}\right]^{2+}(m / z 187)$. The ion intensity of the $\left[K^{\prime} K^{\prime \prime}\right]^{2+}$ parent ion was low, and the signal-to-noise ratio was low; in the spectrum presented, we have therefore removed all peaks (spikes) that only occur in a single channel. The masses of the $c$ and $z$ fragment ions are: $146\left([c+\mathrm{H}]^{+}\right.$from $\left.[\mathrm{KK}+2 \mathrm{H}]^{2+}\right), 188\left([c+\mathrm{H}]^{+}\right.$from $\left[\mathrm{K}^{\prime} \mathrm{K}+\right.$ $\mathrm{H}]^{2+},\left[\mathrm{K}^{\prime} \mathrm{K}^{\prime}\right]^{2+}$, and $\left.\left[\mathrm{K}^{\prime} \mathrm{K}^{\prime \prime}\right]^{2+}\right)$, and $173\left(z^{+\bullet}\right.$ from $\left.\left[\mathrm{KK}^{\prime}+\mathrm{H}\right]^{2+}\right)$.

as hydrogen loss in contrast to the $\mathrm{KK}$ case where hydrogen loss was dominant. Taken together with the findings for $K^{\prime} \mathrm{K}$, it indicates that hydrogen loss occurs after neutralization of a lysine $\varepsilon$-ammonium group whereas ammonia loss is in competition with hydrogen loss after neutralization of an $\mathrm{N}$-terminal ammonium group. These findings are in accordance with ab initio calculations of barrier heights done by Turecek and coworkers [59,60]. Again a tiny peak can be assigned to arise from ions that have lost methyl.

Electron-induced dissociation of $\left[\mathrm{K}^{\prime} \mathrm{K}^{\prime}\right]^{2+}$ gave $[c+$ $\mathrm{H}]^{+}$but no $z^{+}$ions (Figure $2 \mathrm{~d}$ ). The experiment was repeated several times on different days, and sometimes a single peak at $m / z 188$ was measured, and other times the peak shape presented itself as a set of two peaks at $m / z 187.5$ and 188.5 , that is, an equal shift to each side from $\mathrm{m} / \mathrm{z} 188$. The calibration is maximally off by 0.1 mass units. Two peaks at these awkward $\mathrm{m} / \mathrm{z}$ values indicate that potential energy is released into translational energy of the fragments and a discrimina- 
Table 1. Branching ratios (in percentages) for most important product channels after electron capture

\begin{tabular}{|c|c|c|c|c|c|c|c|}
\hline & Intact charge-reduced peptide ion & $\mathrm{H}$ loss $^{\mathrm{a}}$ & $\mathrm{NH}_{3}$ loss $^{\mathrm{a}}$ & Me loss ${ }^{a}$ & $\mathrm{NMe}_{3}$ loss & $z$ lons $^{b}$ & $c$ lons $^{\text {b }}$ \\
\hline$[\mathrm{KK}+2 \mathrm{H}]^{2+}$ & & 37 & 10 & & & & 53 \\
\hline$\left[\mathrm{K}^{\prime} \mathrm{K}+\mathrm{H}\right]^{2+}$ & & 56 & & & & & 44 \\
\hline$\left[\mathrm{KK}^{\prime}+\mathrm{H}\right]^{2+}$ & & 38 & 36 & 2 & & 24 & \\
\hline$\left[K^{\prime} K^{\prime}\right]^{2+}$ & 24 & 4 & & 41 & 12 & & 19 \\
\hline$\left[\mathrm{K}^{\prime} \mathrm{K}+\mathrm{H}\right]^{2+}(\mathrm{CE})$ & 44 & & & 14 & & & 42 \\
\hline$\left[\mathrm{KK}^{\prime}+\mathrm{H}\right]^{2+}(\mathrm{CE})$ & 30 & & 27 & 8 & & 35 & \\
\hline$[\mathrm{AK}+2 \mathrm{H}]^{2+}$ & & 45 & 25 & & & 28 & 2 \\
\hline$\left[\mathrm{AK}^{\prime}+\mathrm{H}\right]^{2+}$ & & 42 & 20 & 1 & & 37 & \\
\hline$\left[\mathrm{AK}^{\prime}+\mathrm{H}\right]^{2+}(\mathrm{CE})$ & & 15 & 42 & 2 & & 41 & \\
\hline$\left[\mathrm{AK}^{\prime}+\mathrm{H}\right]^{2+}(\mathrm{CE})_{2}$ & & 39 & 23 & & 3 & 35 & \\
\hline
\end{tabular}

ancludes the combined loss of $\mathrm{H} / \mathrm{NH}_{3} / \mathrm{Me}$ loss and $\mathrm{CE}$ or $\mathrm{CO}_{2}$ loss.

bIncludes ions with CE attached.

tion against $[c+\mathrm{H}]^{+}$ions not scattered in either the backward or forward direction; the width of the slit before the electrostatic analyzer is narrow $(0.05 \mathrm{~mm})$. Now, we do not understand these day to day variations in the peak shape. The $\mathrm{N}-\mathrm{C}_{\alpha}$ bond cleavage only accounts for $19 \%$ of the yield after electron capture, and the importance of this channel increases in the order $\mathrm{K}^{\prime} \mathrm{K}^{\prime}(19 \%)<\mathrm{KK}^{\prime}(24 \%)<\mathrm{K}^{\prime} \mathrm{K}(44 \%)<\mathrm{KK}(53 \%)$. The intact charge-reduced $\left[\mathrm{K}^{\prime} \mathrm{K}^{\prime}\right]^{+}$ion survived the microsecond flight time to the detector. This finding is in disagreement with neutral reionization experiments on quaternary ammonium ions by Beranová and Wesdemiotis [61]. They found that all hypervalent- $N$ species under study dissociated before reionization since there was no recovery of original parent ions. Shaffer and Turecek [62], on the other hand, found that neutralized hydrogentrimethylammonium has a microsecond lifetime. We also see a shoulder to the $\left[\mathrm{K}^{\prime} \mathrm{K}^{\prime}\right]^{+}$ peak that corresponds to the dehydrogenated ion. For $\mathrm{K}^{\prime} \mathrm{K}^{\prime}$, the loss of methyl is now, as expected, an important channel, and $\mathrm{NMe}_{3}$ loss is also observed.

DFT calculations reveal that the lysine ammonium groups in $\left[\mathrm{K}^{\prime} \mathrm{K}+\mathrm{H}\right]^{2+}$ and $\left[\mathrm{KK}^{\prime}+\mathrm{H}\right]^{2+}$ are both engaged in ionic hydrogen bonding (Figure 3), to the carboxylic acid group and to the $N$-terminal amino group, respectively, which lowers the REs somewhat compared with free ammonium groups. The probability of electron capture by ammonium is, however, still higher than capture by the charge tag based on the higher yield of dehydrogenated ions compared to the yield of intact charge-reduced ions or ions that have lost methyl. The $\left[\mathrm{K}^{\prime} \mathrm{K}^{\prime}\right]^{2+}$ is, not surprisingly, completely unfolded to minimize the Coulomb repulsion between the two charges (Figure 3c).

We will now address the competition between the formation of $[c+\mathrm{H}]^{+}$and $z^{+} \cdot$ ions, that is, which one of the fragments ends up with the charge. The initial cleavage of the $\mathrm{N}-\mathrm{C}_{\alpha}$ bond will result in an evenelectron $c$ fragment and a $z^{+}$radical cation. These may stay together as an ion-molecule complex, which allows for internal hydrogen or proton transfer dependent on the lifetime of the complex [32]. We have found that tagging the ammonium protons by $\mathrm{CE}$ does not prevent $\mathrm{N}-\mathrm{C}_{\alpha}$ bond cleavage but that proton transfer from the $z^{+}$fragment to the $c$ neutral fragment is strongly prohibited. As a result, the dominant ion formed after electron capture by $[\mathrm{KK}+2 \mathrm{H}]^{2+}(\mathrm{CE})$ is $z^{+\bullet}$ and not $[c$ $+\mathrm{H}]^{+}$seen from $[\mathrm{KK}+2 \mathrm{H}]^{+\bullet}[38]$.

It has been possible to explain many of our earlier ECID results based on the Utah-Washington mechanism proposed independently by Simons and Turecek $[14,16]$. In this model, the electron is captured in an amide $\pi^{*}$ orbital that is stabilized by remote charge-carrying groups. The intermediate radical anion or superbase may abstract a proton but this, in principle, is not necessary to explain the facile $\mathrm{N}-\mathrm{C}_{\alpha}$ bond breakage as has been discussed by Turecek and Simons (Figure 4). Also, structural elucidation of $c$-type ions by infrared multiple photon dissociation supports the idea that proton transfer does not occur until after $\mathrm{N}-\mathrm{C}_{\alpha}$ breakage [45]. Proton transfer may not necessarily always take place if the $c$ zwitterion is sufficiently stable. The Utah-Washington mechanism in combination with the possibility of internal proton transfer from $z^{+\bullet}$ to $c$ explains the outcome for $[\mathrm{KK}+2 \mathrm{H}]^{2+}$ and $[\mathrm{KK}+2 \mathrm{H}]^{2+}(\mathrm{CE})$ as discussed above. In the case of $\left[\mathrm{K}^{\prime} \mathrm{K}+\mathrm{H}\right]^{2+}$, internal proton transfer is still an option as it was for $[\mathrm{KK}+2 \mathrm{H}]^{2+}$, and $[c+\mathrm{H}]^{+}$ions are therefore formed. In contrast, for $\left[\mathrm{KK}^{\prime}+\mathrm{H}\right]^{2+}$, there are no longer any ammonium protons that can jump to the $c$ fragment, and $z^{+}$ions appear instead of $[c+\mathrm{H}]^{+}$ions.

Along this line, it is surprising that ECID of $\left[\mathrm{K}^{\prime} \mathrm{K}^{\prime}\right]^{2+}$ gives $[c+\mathrm{H}]^{+}$and not $z^{+}$. Internal protonal transfer (a)

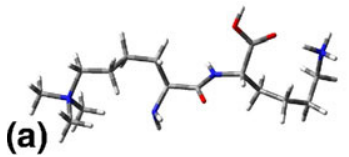

Figure 3. Optimized structures of (a) $\left[\mathrm{K}^{\prime} \mathrm{K}+\mathrm{H}\right]^{2+}$, B3LYP/6-31+G(d,p) level of theory.

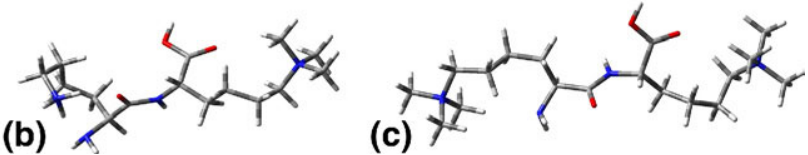

(c)

(b) $\left[K^{\prime}+H\right]^{2+}$, and $(c)\left[K^{\prime} K^{\prime}\right]^{2+}$ at the 


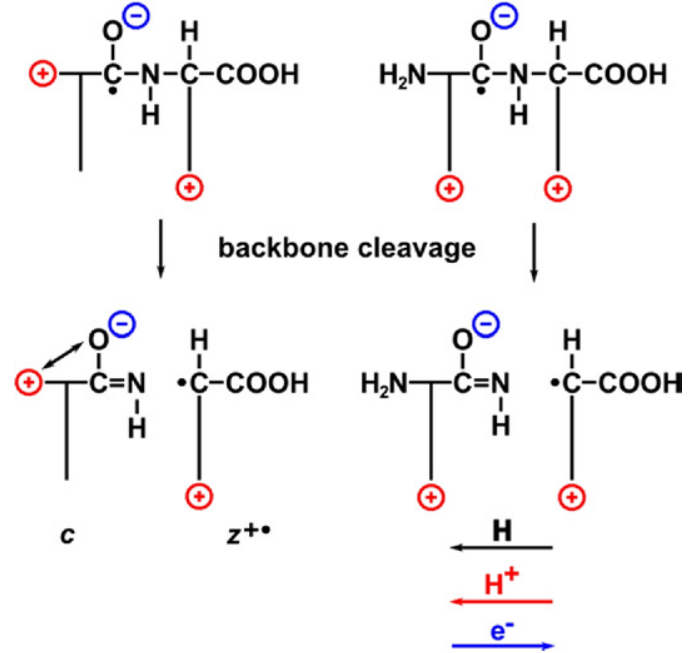

Figure 4. In the Utah-Washington mechanism, the electron is captured by an amide oxygen, which weakens the $\mathrm{N}-\mathrm{C}_{\alpha}$ bond. After breakage the products are a $c$ neutral fragment and a $z$ radical cation but electron or proton jumps may occur to give instead $c^{+}$ions and $z$ neutrals. Hydrogen atom transfer is another possibility but does not change the charge partitioning.

from the carboxyl of the $z$ fragment to the $c$ fragment is ruled out since ECID experiments on the methyl ester $\mathrm{K}^{\prime} \mathrm{K}^{\prime}$ dication $\left(\left[\mathrm{KK}^{\prime \prime}\right]^{2+}\right.$, (see Figure 1) still produced $[c+$ $\mathrm{H}]^{+}$ions (Figure 2e). Notice the significant loss of methyl, which indicates that the ester group competes for the electron. For comparison resonant electron capture by amino acid esters led to methyl loss mediated by a $\pi_{\mathrm{OO}}^{*}$ state [63]. We find it highly unlikely that there is another acidic group of the $z$ fragment that can act as a proton donor, also bearing in mind that $\left[\mathrm{KK}^{\prime}+\mathrm{H}\right]^{2+}$ produced $z^{+}$and not $[c+\mathrm{H}]^{+}$. Hence, we are left with electron-transfer to account for the charge partitioning.

Let us first, however, consider one of the main differences between $\left[\mathrm{K}^{\prime} \mathrm{K}^{\prime}\right]^{+} \bullet^{-}$and $\left[\mathrm{KK}^{\prime}+\mathrm{H}\right]^{+}{ }^{\bullet}$, namely the location of the charge on the $N$-terminal residue. In $K^{\prime} K^{\prime}$, the charges are fixed on each side chain whereas in $\mathrm{KK}^{\prime}$ the ionizing proton is located between the two amino groups. The distances between the negatively charged amide oxygen and the two remote positive charges after electron capture are therefore different in the two cases. In $\left[\mathrm{KK}^{\prime}+\mathrm{H}^{+}{ }^{\bullet}\right.$, the positive charge of the $\mathrm{N}$-terminal residue stabilizes the negative charge more than the remote charge of the side-chain does in $\left[\mathrm{K}^{\prime} \mathrm{K}^{\prime}\right]^{+}$(Figure 4). Indeed, the low yield of backbone fragmentation for the $\mathrm{K}^{\prime} \mathrm{K}^{\prime}$ peptide may be linked to long distances between the amide group and the two charge sites and, as a result, low charge stabilization of the negatively charged amide. Hence, electron capture occurs preferentially to the charge tags.

Now to account for the observation of $c^{+}$ions, we suggest that after breakage of the $\mathrm{N}-\mathrm{C}_{\alpha}$ bond in $\mathrm{K}^{\prime} \mathrm{K}^{\prime}$, the electron is free to jump to the $z^{+\bullet}$ radical to give a carbanion stabilized by the positive charge of the trimethylammonium group (i.e., zwitterion structure). Indeed, neutral $z^{\bullet}$ radicals formed after ECID of monoca- tions readily pick up electrons to become anions as evidenced in charge reversal experiments [64]. The electron affinity $(E A)$ of the neutral ${ }^{\circ} \mathrm{CH}_{2} \mathrm{COOH}$ is quite high, $1.8 \mathrm{eV}$ [65], due to the placement of the negative charge on the carboxylic oxygen, $\mathrm{CH}_{2}=\mathrm{C}(\mathrm{OH}) \mathrm{O}^{-}$. A nearby positive charge will significantly increase this number (by $14.4 \mathrm{eV} \AA / R$ where $R$ is the distance between the two charges). This electron-transfer mechanism in a simple way explains the outcome based on Coulomb interaction energies.

The $c^{+}$ions subsequently abstract hydrogen from a $\mathrm{CH}_{2}$ group of the $z$ fragment to give $[c+\mathrm{H}]^{+}$ions that were measured. $\mathrm{H}$ atom transfer between $z$ and $c$ fragments has been demonstrated to occur with a probability determined by the lifetime of the ionmolecule complex $[32,66]$. Thus, $[c+\mathrm{H}]^{+}$is not a result of proton transfer from $z^{+}$to $c$ but instead due to electron-transfer from $c$ to $z^{+}$followed by hydrogen atom transfer from $z$ to $c^{+}$.

To explore the $z^{\bullet}$ fragments formed, we increased the pressure of Cs in the collision cell to allow for two electron-transfer collisions. The electron capture cross section was, however, very low, and no $z^{-}$anions were observed with certainty. Two fragment ions at $\mathrm{m} / \mathrm{z} 113$ and 157 were detected corresponding to $\left[z-\mathrm{N}\left(\mathrm{CH}_{3}\right)_{3}\right]^{-}$ and $\left[z-\mathrm{CH}_{3}\right]^{-}$, respectively, which suggests that electron capture by the $-\mathrm{N}\left(\mathrm{CH}_{3}\right)_{3}{ }^{+}$group occurred followed by immediate dissociation. The cross section for electron capture is low since the favorable Coulomb interaction between the positive and negative groups is lost. Capture instead by the $\mathrm{CH}^{*}$ radical site is unlikely because electron binding energies of carbanions are quite low. These findings are in accordance with the idea that a neutral $z^{\bullet}$ fragment is formed as a zwitterion after the first electron capture event, but more data are clearly needed to establish its structure.

Next, we studied the supramolecular complexes $\left[\mathrm{K}^{\prime} \mathrm{K}+\mathrm{H}\right]^{2+}(\mathrm{CE})$ and $\left[\mathrm{KK}^{\prime}+\mathrm{H}\right]^{2+}(\mathrm{CE})$. The $\mathrm{CE}$ targets the ammonium group in preference to the trimethylated one, by $1.7 \mathrm{eV}$ according to the model calculations at the B3LYP / 6-311++G(2d,p) level. The singly occupied molecular orbitals (SOMOs) are changed due to the binding of $\mathrm{CE}$ (Figure 5), and it is evident that the location of the extra electron can be accounted for by the relative order of recombination energies of the different groups (vide supra). It should also be mentioned that there is electron density on the amide and carboxylic acid groups.

The $R E$ of $\mathrm{MeNH}_{3}{ }^{+}(\mathrm{CE})$ is lower than that of $\mathrm{NMe}_{4}{ }^{+}$ but the electron can still be captured at both charge sites from the observation of peaks corresponding to loss of $\mathrm{CE}$ and Me from $\left[\mathrm{K}^{\prime} \mathrm{K}+\mathrm{H}\right]^{+\bullet}(\mathrm{CE})$ (Figure 6a). The amount of neutral losses is higher for $\left[\mathrm{KK}^{\prime}+\mathrm{H}^{+}{ }^{+}(\mathrm{CE})\right.$ than that for $\left[\mathrm{K}^{\prime} \mathrm{K}+\mathrm{H}^{+\bullet}(\mathrm{CE})\right.$ but, again, it is evident from the ECID spectrum (Figure 6b) that both charged groups are capture sites. Importantly, the probability for electron capture by the $-\mathrm{NMe}_{3}{ }^{+}$group has clearly gone up for the $\mathrm{CE}$ complexes (compare, Figure $2 \mathrm{bc}$ ). The $c / z$ fragment ions formed are $[c+\mathrm{H}]^{+}$and $[c+$ 

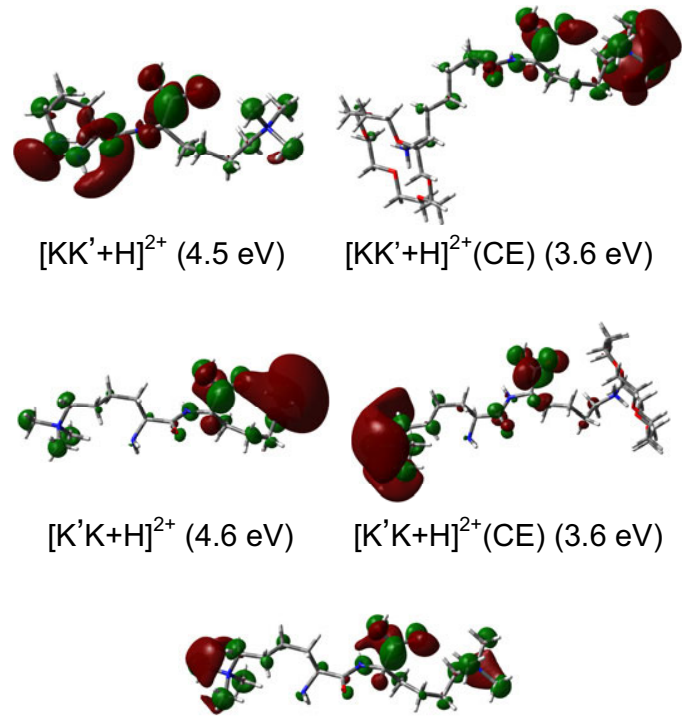

$\left[K^{\prime} K^{\prime}\right]^{2+}(4.1 \mathrm{eV})$

Figure 5. Singly occupied molecular orbitals of charge-reduced peptides. Vertical recombination energies of the corresponding doubly charged ions are given in brackets.

$\mathrm{H}]^{+}(\mathrm{CE})$ for $\left[\mathrm{K}^{\prime} \mathrm{K}+\mathrm{H}\right]^{+\bullet}(\mathrm{CE})$ and $z^{+} \cdot$ and $z^{+\bullet}(\mathrm{CE})$ for $\left[\mathrm{KK}^{\prime}+\mathrm{H}\right]^{+}(\mathrm{CE})$. These data reveal that the $\mathrm{CE}$ is mobile after electron capture and can rearrange to the charge site to maximize the complexation energy. For comparison, photodissociation mass spectroscopy of complexes between protonated tryptophan and CE and between protonated tryptamine and $\mathrm{CE}$ also displayed mobility of $\mathrm{CE}$ since ammonia was lost without the $\mathrm{CE}$ $[67,68]$. In the $z^{+} \cdot(\mathrm{CE})$ fragment, the CE likely interacts with a methyl of the $-\mathrm{NMe}_{3}{ }^{+}$group [69]. The structure of $\left[\mathrm{K}^{\prime} \mathrm{K}+\mathrm{H}\right]^{2+}(\mathrm{CE})$ should resemble that of $\left[\mathrm{K}^{\prime} \mathrm{K}^{\prime}\right]^{2+}$ : In neither of the two ions internal ionic hydrogen bonding is possible, which explains the finding that $\left[\mathrm{K}^{\prime} \mathrm{K}+\right.$ $\mathrm{H}]^{2+}(\mathrm{CE})$ also dissociates into $[c+\mathrm{H}]^{+}$ions. There is no significant difference in the distribution of the two charges in $\left[\mathrm{KK}^{\prime}+\mathrm{H}\right]^{2+}(\mathrm{CE})$ and $\left[\mathrm{KK}^{\prime}+\mathrm{H}\right]^{2+}$ either, and $z^{+} \cdot$ are formed in both cases, likely together with a $c$ zwitterion. These data are, therefore, in support of the mechanism outlined above.

In the Utah-Washington mechanism, the recombination energies of the two charge sites are not directly important for whether $c^{+}$or $z^{+}$ions are formed. The charges only play the role of lowering the energy of the amide $\pi^{*}$ orbital. Proton exchanges may occur after the $\mathrm{N}-\mathrm{C}_{\alpha}$ breakage as discussed before. If, on the other hand, the backbone fragmentation is a result of neutralization of one of the charge sites, the fragment ion formed may strongly depend on differences in REs (at least if subsequent proton transfer is not possible). To further address this point, we carried out another set of experiments on $[\mathrm{AK}+2 \mathrm{H}]^{2+},\left[\mathrm{AK}^{\prime}+\mathrm{H}\right]^{2+},\left[\mathrm{AK}^{\prime}+\right.$ $\mathrm{H}]^{2+}(\mathrm{CE}),\left[\mathrm{AK}^{\prime}+\mathrm{H}\right]^{2+}(\mathrm{CE})_{2}$. For $\left[\mathrm{AK}^{\prime}+\mathrm{H}\right]^{2+}$, the $R E$ of the $\mathrm{N}$-terminal ammonium group is higher than that of the $-\mathrm{NMe}_{3}{ }^{+}$charge tag, whereas $-\mathrm{NMe}_{3}{ }^{+}$has a higher $R E$ than the ammonium group when this is tagged with a CE. The ECID spectra, however, show that $z^{+}$ions are formed in much higher yield than $[c+$ $\mathrm{H}]^{+}$ions in all four cases (Figure 7 and Table 1). If the REs of the two charged groups in $\left[\mathrm{AK}^{\prime}+\mathrm{H}\right]^{2+}(\mathrm{CE})$ were important for the outcome, $c^{+}$and $z$ fragments should initially be formed, and since proton transfer from $c^{+}$to $z$ is prohibited by the CE, this should also be the final fragments after dissociation of the ionmolecule complex. Figure $7 \mathrm{~b}$ and $\mathrm{c}$ show that the loss of methyl is more important for $\left[\mathrm{AK}^{\prime}+\mathrm{H}\right]^{2+}(\mathrm{CE})$ than for $\left[\mathrm{AK}^{\prime}+\mathrm{H}\right]^{2+}$ as expected, but that electron capture by the $-\mathrm{NH}_{3}{ }^{+}(\mathrm{CE})$ is significant, evidenced by the two strong peaks due to loss of ammonia and ammonia + CE. Nonetheless, the lack of $[c+\mathrm{H}]^{+}$ions, even for $\left[\mathrm{AK}^{\prime}+\mathrm{H}\right]^{2+}(\mathrm{CE})$ for which some electron capture definitely occurs by the $-\mathrm{NMe}_{3}{ }^{+}$group is in disfavor of a model where the neutralized charge sites account for the backbone fragmentation. Instead, it is in accordance with a model where the nearby positive charge on the $N$-terminal ammonium group prevents the electron from jumping to the $z^{+}$fragment.

It is found that the probability for $\mathrm{N}-\mathrm{C}_{\alpha}$ bond cleavage decreases in the order: $\left[\mathrm{AK}^{\prime}+\mathrm{H}\right]^{2+}(\mathrm{CE})>$ $\left[\mathrm{AK}^{\prime}+\mathrm{H}\right]^{2+}>[\mathrm{AK}+2 \mathrm{H}]^{2+}$, that is, with increasing $R E$ s of the charge sites. This finding is in keeping with the previous notion that we in ECID can disentangle the two capture events: capture to a charged group results in loss of small neutrals, whereas $\mathrm{N}-\mathrm{C}_{\alpha}$ bond cleavage occurs after capture to the amide group. The competition between the different capture sites is determined

(a)

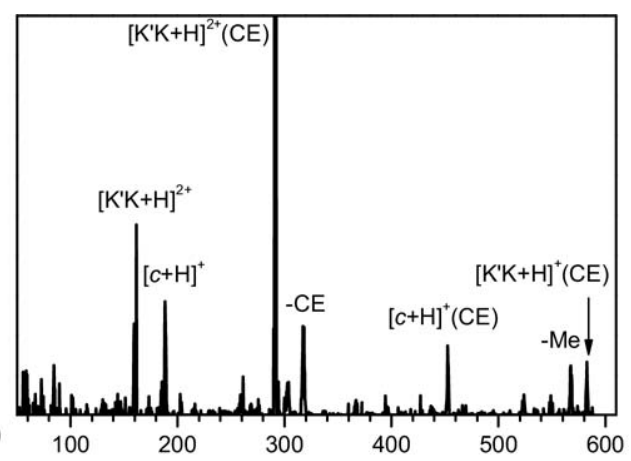

(b)

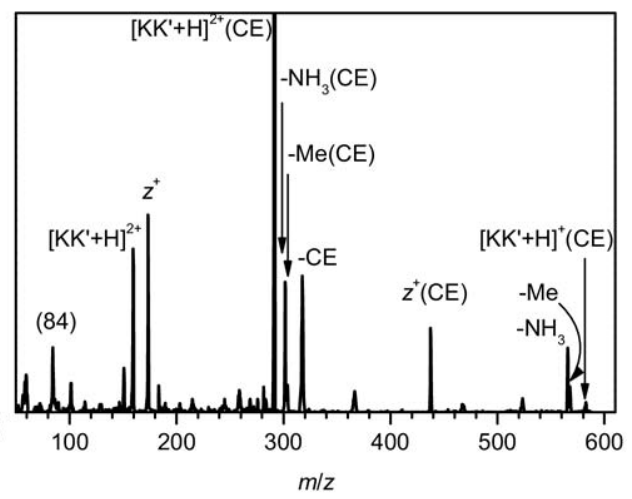

Figure 6. ECID spectra of (a) $\left[\mathrm{K}^{\prime} \mathrm{K}+\mathrm{H}\right]^{2+}(\mathrm{CE})(\mathrm{m} / \mathrm{z} 291)$ and (b) $\left[\mathrm{KK}^{\prime}+\mathrm{H}\right]^{2+}(\mathrm{CE})(\mathrm{m} / \mathrm{z} 291)$. 


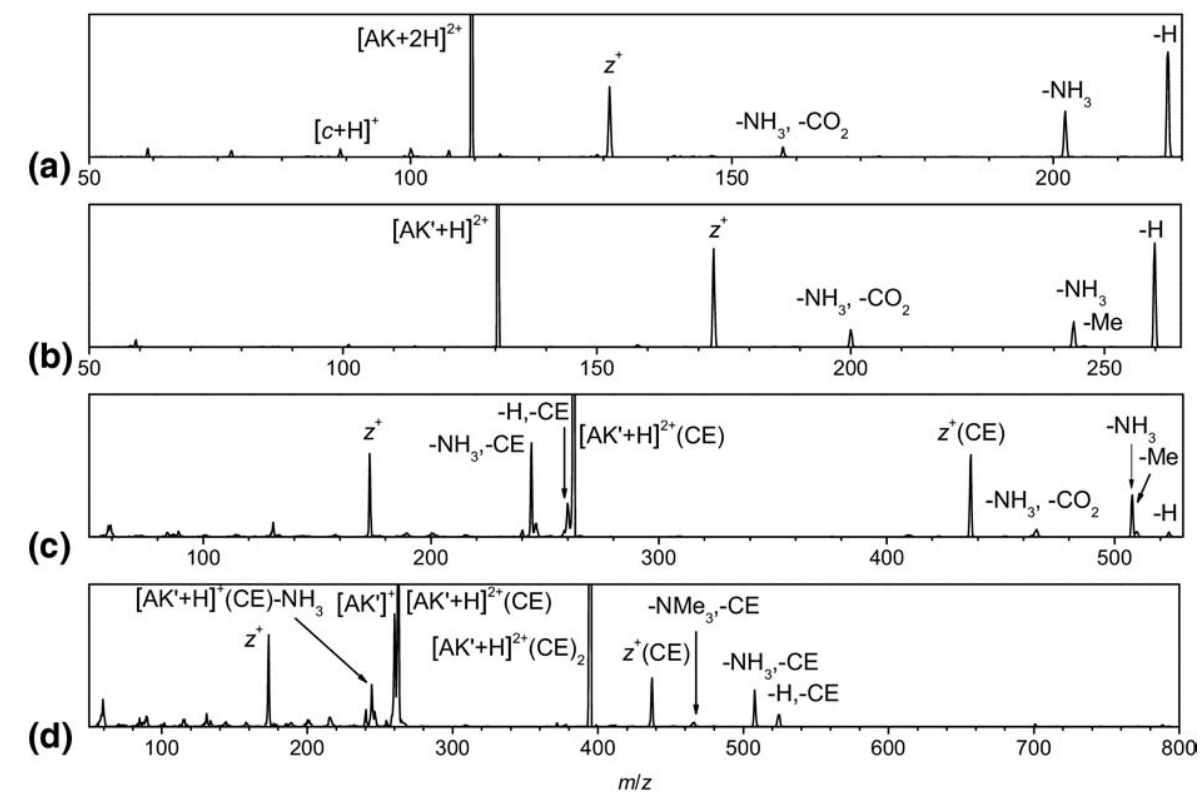

Figure 7. ECID spectra of $(\mathbf{a})[\mathrm{AK}+2 \mathrm{H}]^{2+}(\mathrm{m} / \mathrm{z} 109.5),(\mathbf{b})\left[\mathrm{AK}^{\prime}+\mathrm{H}\right]^{2+}(\mathrm{m} / \mathrm{z} 130.5),(\mathbf{c})\left[\mathrm{AK}^{\prime}+\right.$ $\mathrm{H}]^{2+}(\mathrm{CE})(\mathrm{m} / \mathrm{z} 262.5)$, and (d) $\left[\mathrm{AK}^{\prime}+\mathrm{H}\right]^{2+}(\mathrm{CE})_{2}(\mathrm{~m} / \mathrm{z}$ 394.5). The masses of the $c$ and $z$ fragments are: 89 and $131\left([c+\mathrm{H}]^{+}\right.$and $z^{+\bullet}$ from $\left.[\mathrm{AK}+2 \mathrm{H}]^{2+}\right), 173\left(z^{+}\right.$from $\left.\left[\mathrm{AK}^{\prime}+\mathrm{H}\right]^{2+}\right)$.

by the REs and how closely they match the ionization energy of $\mathrm{Cs}(3.9 \mathrm{eV})$ for resonant electron-transfer.

ECID experiments were also done for $\left[\mathrm{AK}^{\prime}+\mathrm{H}\right]^{2+}$ ions where both the ammonium and the trimethylammonium groups were tagged by crown ether. Here the $R E$ is higher for $-\mathrm{MeNH}_{3}{ }^{+}(\mathrm{CE})$ than that for $-\mathrm{NMe}_{3}{ }^{+}(\mathrm{CE})$. The spectrum did, however, not reveal any noticeable change in the charge partitioning between $z$ and $c$ fragments (Figure 7d). Both $z^{+}$and $z^{+}(\mathrm{CE})$ ions were formed, which indicates that the ions after electron capture and $\mathrm{N}-\mathrm{C}_{\alpha}$ bond cleavage have enough energy to lose crown ether.

Finally, the fact that $z^{+}$ions and not $[c+\mathrm{H}]^{+}$ions were observed for $[\mathrm{AK}+2 \mathrm{H}]^{2+}$ may again be linked to the close proximity of the $N$-terminal ammonium group, which should reduce the proton affinity of the negatively charged amide oxygen. This ammonium group therefore plays a dual role of preventing both electron and proton jumps.

\section{Conclusions}

The dissociation channels of dipeptides after electron capture significantly depend on the introduction of charge and crown ether tags. We have explained the competitive formation of $c^{+}$and $z^{+}$ions based on the idea that the captured electron populates a chargestabilized valence orbital on the amide group (UtahWashington mechanism). In this picture, after $\mathrm{N}-\mathrm{C}_{\alpha}$ bond cleavage not only hydrogen atom and proton transfer between the two fragments determine the outcome but also electron jump from the $c$ to the $z$ fragment in cases where the electron affinity of the $z^{+} \cdot$ is higher than that of the $c^{+} \cdot$ ion. Proton and electron transfer is simply determined by the charge distribution in the ion.

\section{Acknowledgments}

The authors thank Professors Frank Turecek (University of Washington) and Evan R. Williams (University of California, Berkeley) for many enlightening discussions. SBN gratefully acknowledges support from Lundbeckfonden (Junior Group Leader Fellowship), the Danish Natural Science Research Council (grant no. 272-06-0427), and Carlsbergfondet (grant no. 2006-01-0229). AISH acknowledges generous financial support from the EU project ITS-LEIF (RII 3/02 6016).

\section{References}

1. Zubarev, R. A.; Kelleher, N. L.; McLafferty, F. W. Electron capture dissociation of multiply charged protein cations. A nonergodic process. J. Am. Chem. Soc. 1998, 120, 3265-3266.

2. Zubarev, R. A. Reactions of polypeptide ions with electrons in the gas phase. Mass Spectrom. Rev. 2003, 22, 57-77.

3. Sze, S. K.; Ge, Y.; Oh, H. B.; McLafferty, F. W. Plasma electron capture dissociation for the characterization of large proteins by top down mass spectrometry. Anal. Chem. 2003, 75, 1599-1603.

4. Coon, J. J.; Syka, J. E. P.; Schwartz, J. C.; Shabanowitz, J.; Hunt, D. F. Anion dependence in the partitioning between proton and electron transfer in ion/ion reactions. Int. J. Mass Spectrom. 2004, 236, 33-42.

5. Syka, J. E. P.; Coon, J. J.; Schroeder, M. J.; Shabanowitz, J.; Hunt, D. F. Peptide and protein sequence analysis by electron transfer dissociation mass spectrometry. Proc. Natl. Acad. Sci. U.S.A. 2004, 101, 9528-9533.

6. Gunawardena, H. P.; He, M.; Chrisman, P. A.; Pitteri, S. J.; Hogan, J. M. Hodges, B. D. M.; McLuckey, S. A. Electron transfer versus proton transfer in gas-phase ion/ion reactions of polyprotonated peptides. J. Am. Chem. Soc. 2005, 127, 12627-12639.

7. Pitteri, S. J.; Chrisman, P. A.; Hogan, J. M.; McLuckey, S. A. Electron transfer ion/ion reactions in a three-dimensional quadrupole ion trap: Reactions of doubly and triply protonated peptides with $\mathrm{SO} 2$ center dot. Anal. Chem. 2005, 77, 1831-1839.

8. Srikanth, R.; Wilson, J.; Bridgewater, J. D.; Numbers, J. R.; Lim, J.; Olbris, M. R.; Kettani, A.; Vachet, R. W. Improved sequencing of oxidized cysteine and methionine containing peptides using electron transfer dissociation. J. Am. Soc. Mass Spectrom. 2007, 18, 1499-1506.

9. Breuker, K.; Oh, H. B.; Horn, D. M.; Cerda, B. A.; McLafferty, F. W. Detailed unfolding and folding of gaseous ubiquitin ions characterized by electron capture dissociation. J. Am. Chem. Soc. 2002, 124, 6407-6420.

10. Turecek, F. N-C $\alpha$ bond dissociation energies and kinetics in amide and peptide radicals. Is the dissociation a non-ergodic process?. J. Am. Chem. Soc. 2003, 125, 5954-5963.

11. Breuker, K.; Oh, H. B.; Lin, C.; Carpenter, B. K.; McLafferty, F. W. Nonergodic and conformational control of the electron capture dissociation of protein cations. Proc. Natl. Acad. Sci. U.S.A. 2004, 101, 14011-14016. 
12. Jones, J. W.; Sasaki, T.; Goodlett, D. R.; Turecek, F. Electron capture in spin-trap capped peptides. An experimental example of ergodic dissociation in peptide cation-radicals. I. Am. Soc. Mass Spectrom. 2007, 18, 432-444.

13. Turecek, F.; Syrstad, E. A.; Seymour, J. L.; Chen, X. H.; Yao, C. X. Peptide cation-radicals. A computational study of the competition between peptide $\mathrm{N}-\mathrm{C} \alpha$, bond cleavage and loss of the side chain in the [GlyPhe-NH2 + $2 \mathrm{H}]^{+}$cation-radical. J. Mass Spectrom. 2003, 38, 1093-1104.

14. Syrstad, E. A.; Turecek, F. Toward a general mechanism of electron capture dissociation. J. Am. Soc. Mass Spectrom. 2005, 16, 208-224.

15. Anusiewicz, W.; Berdys-Kochanska, J.; Simons, J. Electron attachment step in electron capture dissociation (ECD) and electron transfer dissociation (ETD). J. Phys. Chem. A 2005, 109, 5801-5813.

16. Sobczyk, M.; Anusiewicz, W.; Berdys-Kochanska, J.; Sawicka, A.; Skurski, P.; Simons, J. Coulomb-assisted dissociative electron attachment: Application to a model peptide. J. Phys. Chem. A 2005, 109, 250-258.

17. Sawicka, A. Skurski, P. Hudgins, R. R. Simons, J. Model calculations relevant to disulfide bond cleavage via electron capture influenced by positively charged groups. J. Phys. Chem. B 2003, 107, 13505-13511.

18. Sawicka, A.; Anusiewicz, I.; Skurski, P.; Simons, J. Dipole-bound anions supported by charge-transfer interaction: Anionic states of HnF3-nN $->$ $\mathrm{BH} 3$ and $\mathrm{H} 3 \mathrm{~N}->$ BHnF3-n $(n=0,1,2,3)$. Int. J. Ouant. Chem. 2003, 92, 367-375

19. Chamot-Rooke, J.; Malosse, C.; Frison, G.; Turecek, F. Electron capture in charge-tagged peptides. Evidence for the role of excited electronic states. I. Am. Soc. Mass Spectrom. 2007, 18, 2146-2161.

20. Turecek, F.; Jones, J. W.; Holm, A. I. S.; Panja, S.; Brøndsted Nielsen, S.; Hvelplund, P. Transition metals as electron traps. I. Structures, energetics, electron capture, and electron-transfer-induced dissociations of ternary copper-peptide complexes in the gas phase. J. Mass Spectrom. 2009, 44, 707-724.

21. Chung, T. W.; Turecek, F. Electronic properties of charge-tagged peptides upon electron capture. Eur. J. Mass Spectrom. 2008, 14, 367-378

22. Kjeldsen, F.; Savitski, M. M.; Adams, C. M.; Zubarev, R. A. Determination of the location of positive charges in gas-phase polypeptide polycations by tandem mass spectrometry. Int. J. Mass Spectrom. 2006, $252,204-212$.

23. Turecek, F.; Chen, X. H.; Hao, C. T. Where does the electron go? Electron distribution and reactivity of peptide cation radicals formed by electron transfer in the gas phase. I. Am. Chem. Soc. 2008, 130, 8818-8833.

24. Kruger, N. A.; Zubarev, R. A.; Horn, D. M.; McLafferty, F. W. Electron capture dissociation of multiply charged peptide cations. Int. J. Mass Spectrom. 1999, 187, 787-793.

25. Zubarev, R. A.; Horn, D. M.; Fridriksson, E. K.; Kelleher, N. L.; Kruger N. A.; Lewis, M. A.; Carpenter, B. K.; McLafferty, F. W. Electron capture dissociation for structural characterization of multiply charged protein cations. Anal. Chem. 2000, 72, 563-573.

26. Crizer, D. M.; McLuckey, S. A. Electron transfer dissociation of amide nitrogen methylated polypeptide cations. J. Am. Soc. Mass Spectrom. 2009, in press

27. Lin, C.; Cournoyer, J. J.; O'Connor, P. B. Probing the gas-phase folding kinetics of peptide ions by IR activated DR-ECD. J. Am. Soc. Mass Spectrom. 2008, 19, 780-789.

28. Mihalca, R.; Kleinnijenhuis, A. J.; McDonnell, L. A.; Heck, A. J. R.; Heeren, R. M. A. Electron capture dissociation at low temperatures reveals selective dissociations. J. Am. Soc. Mass Spectrom. 2004, 15, 1869-1873.

29. Robinson, E. W.; Leib, R. D.; Williams, E. R. The role of conformation on electron capture dissociation of ubiquitin. J. Am. Soc. Mass Spectrom. 2006, 17, 1469-1479.

30. Ehlerding, A.; Jensen, C. S.; Wyer, J. A.; Holm, A. I. S.; Jørgensen, P.; Kadhane, U.; Larsen, M. K.; Panja, S.; Poully, J. C.; Worm, E. S.; Zettergren, H.; Hvelplund, P.; Brøndsted Nielsen, S. Influence of temperature and crown ether complex formation on the charge partitioning between $z$ and $c$ fragments formed after electron capture by small peptide dications. Int. J. Mass Spectrom. 2009, 282, 21-27.

31. Zubarev, R. A.; Kruger, N. A.; Fridriksson, E. K.; Lewis, M. A.; Horn, D. M.; Carpenter, B. K.; McLafferty, F. W. Electron capture dissociation of gaseous multiply-charged proteins is favored at disulfide bonds and other sites of high hydrogen atom affinity. J. Am. Chem. Soc. 1999, 121, 2857-2862.

32. O'Connor, P. B.; Lin, C.; Cournoyer, J. J.; Pittman, J. L.; Belyayev, M. Budnik, B. A. Long-lived electron capture dissociation product ions experience radical migration via hydrogen abstraction. J. Am. Soc. Mass Spectrom. 2006, 17, 576-585.

33. Savitski, M. M.; Kjeldsen, F.; Nielsen, M. L.; Zubarev, R. A. Hydrogen rearrangement to and from radical $z$ fragments in electron capture dissociation of peptides. J. Am. Soc. Mass Spectrom. 2007, 18, 113-120.

34. Leymarie, N.; Costello, C. E.; O'Connor, P. B. Electron capture dissociation initiates a free radical reaction cascade. J. Am. Chem. Soc. 2003, 125, 8949-8958.

35. Siu, C. K.; Ke, Y.; Orlova, G.; Hopkinson, A. C.; Siu, K. W. M. Dissociation of the $\mathrm{N}-\mathrm{C} \alpha$ bond and competitive formation of the $[\mathrm{z}$ (n) $-\mathrm{H}]^{+}$and $[\mathrm{c}(\mathrm{n})+2 \mathrm{H}]^{+}$product ions in radical peptide ions containing tyrosine and tryptophan: The influence of proton affinities on product formation. I. Am. Soc. Mass Spectrom. 2008, 19, 1799-1807.

36. Rand, K. D.; Adams, C. M.; Zubarev, R. A.; Jørgensen, T. J. D. Electron capture dissociation proceeds with a low degree of intramolecular migration of peptide amide hydrogens. J. Am. Chem. Soc. 2008, 130, 1341-1349.
37. Bakken, V.; Helgaker, T.; Uggerud, E. Models of fragmentations induced by electron attachment to protonated peptides. Eur. J. Mass Spectrom. 2004, 10, 625-638

38. Holm, A. I. S.; Hvelplund, P.; Kadhane, U.; Larsen, M. K.; Liu, B. Brøndsted Nielsen, S.; Panja, S.; Pedersen, J. M.; Skrydstrup, T.; Støchkel, K.: Williams, E. R.; Worm, E. S. On the mechanism of electroncapture-induced dissociation of peptide dications from N-15-labeling and crown-ether complexation. J. Phys. Chem. A 2007, 111, 9641-9643.

39. Chakraborty, T.; Holm, A. I. S.; Hvelplund, P.; Brøndsted Nielsen, S.; Poully, J. C.; Worm, E. S.; Williams, E. R. On the survival of peptide cations after electron capture: Role of internal hydrogen bonding and microsolvation. I. Am. Soc. Mass Spectrom. 2006, 17, 1675-1680.

40. Prell, J. S.; O’Brien, J. T.; Holm, A. I. S.; Leib, R. D.; Donald, W. A.; Williams, E. R. Electron capture by a hydrated gaseous peptide: Effects of water on fragmentation and molecular survival. J. Am. Chem. Soc $2008,130,12680-12689$

41. Zettergren, H.; Adoui, L.; Bernigaud, V; Cederquist, $\mathrm{H}$; Haag, N Holm, A. I. S.; Huber, B. A.; Hvelplund, P.; Johansson, H.; Kadhane, U. Larsen, M. K.; Liu, B.; Manil, B.; Brøndsted Nielsen, S.; Panja, S.; Rangama, J.; Reinhed, P. R.; Schmidt, T.; Støchkel, K. Electron-captureinduced dissociation of microsolvated di- and tripeptide monocations: Elucidation of fragmentation channels from measurements of negative ions. Chem. Phys. Chem. 2009, 10, 1619-1623.

42. Iavarone, A. T.; Paech, K.; Williams, E. R. Effects of charge state and cationizing agent on the electron capture dissociation of a peptide. Anal. Chem. 2004, 76, 2231-2238.

43. Liu, H.; Hakansson, K. Electron capture dissociation of tyrosine Osulfated peptides complexed with divalent metal cations. Anal. Chem. 2006, 78, 7570-7576.

44. Liu, H. C.; Hakansson, K. Divalent metal ion-peptide interactions probed by electron capture dissociation of trications. J. Am. Soc. Mass Spectrom. 2006, 17, 1731-1741.

45. Frison, G.; van der Rest, G.; Turecek, F.; Besson, T.; Lemaire, J.; Maitre P.; Chamot-Rooke, J. Structure of electron-capture dissociation fragments from charge-tagged peptides probed by tunable infrared multiple photon dissociation. J. Am. Chem. Soc. 2008, 130, 14916-14917.

46. Li, X. J.; Cournoyer, J. J.; Lin, C.; O'Connor, P. B. The effect of fixed charge modifications on electron capture dissociation. J. Am. Soc. Mass Spectrom. 2008, 19, 1514-1526.

47. Xia, Y.; Gunawardena, H. P.; Erickson, D. E.; McLuckey, S. A. Effects of cation charge-site identity and position on electron-transfer dissociation of polypeptide cations. J. Am. Chem. Soc. 2007, 129, 12232-12243.

48. Fung, Y. M. E.; Liu, H. C.; Chan, T. W. D. Electron capture dissociation of peptides metalated with alkaline-earth metal ions. J. Am. Soc. Mass Spectrom. 2006, 17, 757-771.

49. Chung, T. W.; Turecek, F. Selecting fixed-charge groups for electronbased peptide dissociations - a computational study of pyridinium tags. Int. J. Mass Spectrom. 2008, 276, 127-135.

50. Chamot-Rooke, J.; van der Rest, G.; Dalleu, A.; Bay, S.; Lemoine, J. The combination of electron capture dissociation and fixed charge derivatization increases sequence coverage for O-glycosylated and Ophosphorylated peptides. J. Am. Soc. Mass Spectrom. 2007, 18, 1405-1413.

51. Gunawardena, H. P.; Gorenstein, L.; Erickson, D. E.; Xia, Y.; McLuckey S. A. Electron transfer dissociation of multiply protonated and fixed charge disulfide linked polypeptides. Int. J. Mass Spectrom. 2007, 265, 130-138.

52. Hvelplund, P.; Liu, B.; Brøndsted Nielsen, S.; Tomita, S. Electron capture induced dissociation of peptide dications. Int. J. Mass Spectrom. 2003, 225, 83-87

53. Bernigaud, V.; Cederquist, H.; Haag, N.; Holm, A. I. S.; Huber, B. A.; Hvelplund, P.; Kadhane, U.; Larsen, M. K.; Manil, B.; Brøndsted Nielsen, S. Panja, S. Ptasinska, S. Rangama, J · Reinhed, P. Schmidt, H. T.; Streletskii, A. V.; Støchkel, K.; Worm, E. S.; Zettergren, H. Electron capture-induced dissociation of AK dipeptide dications: Influence of ion velocity, crown-ether complexation, and collision gas. Int. J. Mass Spectrom. 2008, 276, 77-81.

54. Boltalina, O. V.; Hvelplund, P.; Jørgensen, T. J. D.; Larsen, M. C.; Larsson, M. O.; Sharoitchenko, D. A. Electron capture by fluorinated fullerene anions in collisions with Xe atoms. Phys. Rev. A 2000, 62, 023202.

55. Larsson, M. O.; Hvelplund, P.; Larsen, M. C.; Shen, H.; Cederquist, H. Schmidt, H. T. Electron capture and energy loss in similar to $100 \mathrm{keV}$ collisions of atomic and molecular ions on C-60. Int. J. Mass Spectrom 1998, 177, 51-62.

56. Frisch, M. J.; Trucks, G. W.; Schlegel, H. B.; Scuseria, G. E.; Robb, M. A.; Cheeseman, J. R.; Montgomery, J. A.; Vreven, T.; Kudin, K. N.; Burant J. C.; Millam, J. M.; Iyengar, J.; Tomasi, J.; Barone, V.; Mennucci, B. Cossi, M.; Scalmani, G.; Rega, N.; Petersson, G. A.; Nakatsuji, H.; Hada M.; Ehara, M.; Toyota, K.; Fukuda, R.; Hasegawa, J.; Ishida, M. Nakajima, T.; Honda, Y.; Kitao, O.; Nakai, H.; Klene, M.; Li, X.; Knox, J. E.; Hratchian, H. P.; Cross, J. B.; Adamo, C.; Jaramillo, J.; Gomperts, R.; Strattman, R. E.; Yazyev, O.; Austin, A. J.; Cammi, R.; Pomelli, C.; Ochterski, J. W.; Ayala, P. Y.; Morokuma, K.; Voth, G. A.; Salvador, P.; Dannenberg, J. J.; Zakrzewski, V. G.; Apprich, S.; Daniels, A. D.; Strain, M. C.; Farkas, O.; Malick, D. K.; Rabuck, A. D.; Raghavachari, K.; Foresman, J. B.; Ortiz, J. V.; Cui, Q.; Baboul, A. G.; Clifford, S.; Cioslowski, J.; Stefanov, B. B.; Liu, G.; Liashenko, A.; Piskorz, P. Komaromi, I.; Martin, R. L.; Fox, D. J.; Keith, T.; Al-Laham, M. A.; Peng, C. Y.; Nanayakkara, A.; Challacombe, M.; Gill, P. M. W.; Johnson, B. Chen, W.; Wong, M. W.; Gonzalez, C.; Pople, J. A. Gaussian 03, Revision B. 05; Gaussian, Inc.: Pittsburgh, PA, 2003.

57. Becke, A. D. Density-Functional Thermochemistry. III. The Role of Exact Exchange. J. Chem. Phys. 1993, 98, 5648-5652. 
58. Lee, C.; Yang, W.; Parr, R. G. Development of the Colle-Salvetti correlation-energy formula into a functional of the electron density. Phys. Rev. B 1988, 37, 785 .

59. Turecek, F.; Syrstad, E. A. Mechanism and energetics of intramolecular hydrogen transfer in amide and peptide radicals and cation-radicals. J. Am. Chem. Soc. 2003, 125, 3353-3369.

60. Yao, C. X.; Syrstad, E. A.; Turecek, F. Electron transfer to protonated $\beta$-alanine $\mathrm{N}$-methylamide in the gas phase: An experimental and computational study of dissociation energetics and mechanisms. J. Phys. Chem. A 2007, 111, 4167-4180.

61. Beranova, S.; Wesdemiotis, C. The Unimolecular Chemistry of Quaternary Ammonium-Ions and Their Neutral Counterparts. Int. J. Mass Spectrom. Ion Processes 1994, 134, 83-102.

62. Shaffer, S. A.; Turecek, F. Hydrogentrimethylammonium-a marginally stable hypervalent radical. J. Am. Chem. Soc. 1994, 116, 8647-8653.

63. Vasil'ev, Y. V.; Figard, B. J.; Voinov, V. G.; Barofsky, D. F.; Deinzer, M. L. Resonant electron capture by some amino acids and their methyl esters. J. Am. Chem. Soc. 2006, 128, 5506-5515.

64. Hvelplund, P.; Liu, B.; Brøndsted Nielsen, S.; Panja, S.; Poully, J. C.; Støchkel, K. Electron capture induced dissociation of peptide ions: Identification of neutral fragments from secondary collisions with cesium vapor. Int. J. Mass Spectrom. 2007, 263, 66-70.
65. Wyer, J. A.; Feketeova, L.; Brøndsted Nielsen, S.; O'Hair, R. A. J. Gas phase fragmentation of betaine and its clusters. Phys. Chem. Chem. Phys. 2009, doi:10.1039/B909653A.

66. Tsybin, Y. O.; He, H.; Emmett, M. R.; Hendrickson, C. L.; Marshall, A. G Ion activation in electron capture dissociation to distinguish between $\mathrm{N}$-terminal and C-terminal productions. Anal. Chem. 2007, 79, 75967602.

67. Kadhane, U.; Andersen, J. U.; Ehlerding, A.; Hvelplund, P.; Kirketerp, M. B. S.; Lykkegaard, M. K.; Brøndsted Nielsen, S.; Panja, S.; Wyer, J. A. Zettergren, H. Photodissociation of protonated tryptophan and alteration of dissociation pathways by complexation with crown ether. J. Chem. Phys. 2008, 129, 184304.

68. Kadhane, U.; Perot, M.; Lucas, B.; Barat, M.; Fayeton, J. A.; Jouvet, C. Ehlerding, A.; Kirketerp, M.-B. S.; Brøndsted Nielsen, S.; Wyer, J. A. Zettergren, $\mathrm{H}$. Photodissociation of protonated tryptamine and its supramolecular complex with 18-crown-6 ether: Dissociation times and channels, absorption spectra, and excited states calculations, unpublished.

69. Franski, R.; Gierczyk, B. Unusual complex between 18-Crown-6 and tetramethylammonium cation-detection by electrospray ionization mass spectrometry. J. Inclusion Phenom. Macrocyc. Chem. 2008, 62, 339343. 